\title{
Interpretation of the Decision of the Standing Committee of the National People's Congress of China to Abolish the Bad Habit of Consuming Wildlife Mindlessly
}

\section{Jiwen Chang}

Deputy director and professor of Institute of Resources and Environmental Policy of the Development Research Center of the State Council, adjunct professor of Hunan University Law School and School of Humanities and Economics and Management of the China University of Geosciences, and a professor of the Capital University of Economics and Business Law School, China

Recommended citation. CHANG, J., Interpretation of the Decision of the Standing Committee of the National People's Congress of China to Abolish the Bad Habit of Consuming Wildlife Mindlessly, dA. Derecho Animal (Forum of Animal Law Studies) 11/2 (2020). - DOI https://doi.org/10.5565/rev/da.497

\begin{abstract}
In order to eliminate the risk of potential disease spreading between people and wildlife, and to safeguard public health security of the society, as well as to maintain the ecological balance, the Standing Committee of the National People's Congress of China passed the decision to abolish the bad habit of consuming wildlife mindlessly in February 2020, which stipulated the scope of the fasting, measures of punishment, scope of edible livestock and poultry, and the special conditions and approval measures of non-edible utilization of wild animals, etc. The "Decision" reflects the practical and realistic legislative attitude: it not only eliminates the bad habits, but also provides the provisions of special conditions for captive breeding, which safeguard the basic stability of the economy. The method of combining Blacklist and Whitelist is adopted to delimit the boundary between illegal and legal. The whole chain of legal norms is constructed, which stipulated the applicable or suggested applicable legal liabilities for illegal acts and served as the "talons" of the law that brought it into play.
\end{abstract}

Key words: wildlife; livestock and poultry; prohibition; eating mindlessly; infectious diseases.

Resumen - Interpretación de la Decisión del Comité Permanente del Congreso Nacional del Pueblo de China de abolir el mal hábito de consumir fauna silvestre irresponsablemente

Con el objetivo de eliminar el riesgo de una potencial propagación de enfermedades entre personas y fauna silvestre, y salvaguardar la seguridad de la salud pública de la sociedad, así como mantener el equilibrio ecológico, el Comité Permanente del Congreso Nacional del Pueblo de China aprobó, en febrero de 2020, la decisión de abolir el mal hábito de consumir fauna silvestre irresponsablemente, que establece el alcance de la prohibición, las sanciones, la importancia del ganado y las aves de corral comestibles, las condiciones especiales y las medidas de utilización no comestible de animales silvestres, etc. La "Decisión" refleja una actitud legislativa práctica y realista: no solo elimina los malos hábitos, sino que también proporciona las condiciones especiales para la cría en cautividad, que salvaguardan la estabilidad económica. Se adopta el método de combinar la Lista Negra y la Lista Blanca para delimitar la barrera entre ilegal y legal. Se construye todo el conjunto de normas jurídicas, que establecen las responsabilidades frente a conductas ilícitas, y que constituyen los "pilares" de la ley que entró en vigor.

Palabras clave: fauna silvestre; ganado y aves de corral; prohibición; consumo irresponsable; enfermedades infecciosas. 


\section{The Background of the Decision of the Standing Committee}

During the prevention and control of COVID-19 in China, on February 24th, 2020, the Standing Committee of the National People's Congress deliberated and adopted "The Decision on Comprehensively Banning the Illegal Wildlife Trade, Abolishing the Bad Habit of Eating Wildlife Mindlessly, and Effectively Protecting the Health and Safety of the People" (the "Decision"). The consumption of wildlife is a historical phenomenon across the world. From primitive society, agricultural society to the current industrialized society, the consumption of wildlife exists in different degrees across the world. Then why did the Standing Committee of the National People's Congress adopt the "Decision" at this time? The main reason is that the existing provisions of the "Wildlife Protection Act" on the prohibition of the consumption of wild animals are insufficient, which need to be amended on the basis of the principle of biosafety risk prevention. ${ }^{1}$

According to the provisions of the criminal law and the judicial interpretation of the People's Supreme Court, criminal responsibility shall be borne for the consumption of wildlife and the purchase of wildlife and its products under special state protection for the purpose of consumption, and for the hunting of a certain number of animals with "three values", which are wild animals with important scientific research, ecological protection and social value. However, as for the consumption of animals with "three values" and general wildlife, such as bats, mice and rabbits, which may cause public health diseases, "the Criminal Law" and "the Wildlife Protection Act" do not stipulate the requirements of the prohibition, ${ }^{2}$ resulting in the persistence of the bad social habits of eating wildlife mindlessly.

As for now, although there is no certain scientific evidence to prove that the COVID-19 is entirely caused by the illegal trading and eating of wildlife. Based on current scientific research, the similarity between the virus found in the body of a pangolin and the COVID - 19 virus is $99 \%,{ }^{3}$ and the similarity between the virus found in the body of a bat in Yunnan province and the COVID-19 is $96 \%,{ }^{4}$ which are extremely high, which indicates the original host of the COVID -19 is virtually certain to come from wildlife. Because of the severity of the situation in response to the COVID-19 incident, we cannot withhold or delay preventive measures just because the similarity is less than 100 percent. For this situation, the United Nations Rio Declaration on Environment and Development in 1992, article 15 established the "precautionary principle", namely that the country should base decisions on its ability to widely adopt precautionary measures to protect the environment. When it comes to the threat of serious or irreversible damage, lacking full scientific certainty should not be the reason for the delay of the cost-effective measures to prevent environmental degradation. The principle of precautionary measures is also recognized in the "Convention on Biological Diversity" and the "Cartagena Protocol on Biosafety to the Convention on Biological Diversity". As a state party to these treaties, China should abide by this principle and translate it into the basic principles and specific provisions of "the Wildlife Protection Act" and "the Animal Epidemic Prevention Act" through domestic legislation. ${ }^{5}$

The SARS outbreak in 2003 and the COVID-19 outbreak started in late 2019 were highly likely caused by the consumption of wildlife. These two incidents have caused great losses and people in China have reacted strongly to the problem of eating mindlessly of wildlife and serious threats to public health safety. In order to prevent the recurrence of similar public health incidents, we must cut off the disease transmission channels between people and wildlife. Thus, "the Wildlife Protection Act" must be amended. ${ }^{6}$ Given that it will take at least half a year for China's laws to be revised and the emergency response to COVID-19 is urgently needed, it was wise and practical for the Standing Committee of the National People's Congress to issue an emergency decision $^{7}$ on the scope of fasting and the elimination of the bad habit of eating wildlife mindlessly.

\footnotetext{
${ }^{1}$ See ZHANG, K., An interview with Jiwen Chang: COVID - 19 is an alarm, in principle we should be fasting all the wildlife, the First Finance and Economics, on February 8, 2020: https://baijiahao.baidu.com/s?Id = 1657940428583239647 \& WFR = spider\&for $=\mathrm{PC}$

${ }^{2}$ See ZHANG, K., An interview with Jiwen Chang: COVID - 19 is an alarm, in principle we should be fasting all the wildlife, the First Finance and Economics, on February 8, 2020: https://baijiahao.baidu.com/s? Id = 1657940428583239647 \& WFR = spider\&for $=\mathrm{PC}$

${ }^{3}$ See LIU, M., Experts: Pangolin May Not be the Only Potential Intermediate Host of the Novel Coronavirus", Beijing News, February 7, 2020

${ }^{4}$ See WANG, J., 96\%! The Novel Coronavirus Has a High Similarity with the Virus in a Bat Sample, Contemporary Business Daily, February 9, 2020.

${ }^{5}$ See CHANG, J., CHANG, J., A Legal Decision Embodies Social Civilization and Ecological Progress, China Environment News, February 27, 2020.

${ }^{6}$ See LU, H., YANG, B., Complete Ban of Illegal Wildlife Trade and Elimination of Eating Wildlife Mindlessly: Answers to Questions from the Press By the Head of the Legislative Affairs Commission of the Standing Committee of the National People's Congress: http://www.npc.gov.cn/npc/c30834/202002/fe45c9fbd7a647d595d23601bc75c8fb.shtml

${ }^{7}$ See LU, H., YANG, B., Complete Ban of Illegal Wildlife Trade and Elimination of Eating Wildlife Mindlessly: Answers to Questions from the Press By the Head of the Legislative Affairs Commission of the Standing Committee of the National People's Congress: http://www.npc.gov.cn/npc/c30834/202002/fe45c9fbd7a647d595d23601bc75c8fb.shtml
} 


\section{The main contents of the decision}

The full text of the decision is divided into two parts: the issuing purpose of the decision and specific provisions. There are eight specific provisions, among which Article I and Article II stipulate the scope of the fasting on wildlife and the punishment measures for illegal acts; Article III specifies the scope of edible livestock and poultry; Article IV stipulates the special cases for non-food uses of wildlife and its measures for examination and approval; Article V stipulates publicity and public education measures; Article VI stipulates the requirements for the law enforcement and measures; Article VII stipulates the formulation and adjustment of the black list and white list, as well as supplementary provisions; and Article VIII specifies the enforcement date of the "Decision".

The purpose of the "Decision", which was illustrated at the beginning of this document, is to completely ban and punish the illegal wildlife trade and to abolish the bad habit of eating wildlife mindlessly, to maintain biological and ecological security and effectively prevent major public health risks, to protect people's health and safety, and to strengthen the construction of ecological civilization as well as to promote the harmonious coexistence between man and nature. The purpose of the "Decision" includes ecological protection and the protection of the public health, as well as promoting citizens to form civilized lifestyles. From the macro perspective, the "Decision", aims at protecting people's lives and health and uses the precautionary principle as the legislative foundation of the total ban on illegal wildlife trade and consume wildlife mindlessly is scientific. It is worth noting that the "Decision" does not mean that the outbreak of COVID-19 was actually caused by eating wild animals, but rather it is intended to cut off the transmission channel of infectious diseases between humans and wildlife. ${ }^{8}$

As for the scope of the prohibition on the consumption of wildlife, Article I of the "Decision" stipulates that the hunting, trading, transporting, and eating of wildlife that are prohibited by the "the Wildlife Protection Act" and other relevant laws must be strictly prohibited. This means that wildlife under special state protection and provincial protection are prohibited from hunting, trading, transporting, or eating. For those who violate the law, the "Decision" stipulates that the punishment shall be aggravated on the basis of the existing law. The increased penalties mean that fines are more severe than before. Article II of the "Decision" stipulates that there is a total ban on the consumption of wildlife with "three values" and other terrestrial wild animals, including those bred and reared in captivity, and a total ban on the hunting, trading, and transporting of terrestrial wildlife that live and breed naturally in the wild for the purpose of food. This means that where it used to be legal to raise wild animals such as snakes, pheasants, wigeons, and peacocks it is now illegal. It is now also illegal to eat sparrows, locusts, scorpions, and cicadas from nature. As there is no provision for punishment measures in the current law, the "Decision" stipulates that for illegal acts, relevant provisions of the current law about punishment shall be applied.

As for the range of edible livestock and poultry, Article III of the "Decision" stipulates that animals listed under the catalogue of livestock and poultry genetic resources belong to livestock and poultry, and the provisions of the "Livestock Law of the People's Republic of China" shall apply. This means that a few wild animals, such as Aolugaya reindeer and Jilin sika deer, can be eaten and raised in captivity because they have been included in the livestock and poultry genetic resources catalogue.

As for the special situation of the non-edible use of wild animals, Article IV of the "Decision" provides only three kinds of exceptions, which are the use for the purpose of scientific research, medicine, and exhibition. For these exceptional cases, strict examination and approval and quarantine inspection shall also be carried out in accordance with the relevant provisions of the state. The "Decision" also requires the State Council and its relevant competent departments to promptly formulate and improve regulations on the approval and quarantine inspection of the non-edible use of wild animals and strictly implement them. This means that some traditional Chinese medicines that use wild animals as formula may be rejected if there are alternatives to using wild animals. However, some law enforcement officials pointed out that this exception should also apply to raising fur-bearing animals, which has been criticized by scholars.

About publicity and public education measures, Article V of the "Decision" stipulates that the people's governments at various levels and social organizations, schools, the news media, and other social aspects shall actively carry out publicity, education, and guidance on ecological and environmental protection as well as public health safety. The members of the society should strengthen ecological protection and public health security consciousness and abolish the bad habit of eating wildlife mindlessly, so that we can develop scientific, healthy, and civilized lifestyles. This is beneficial to maintaining the international image of Chinese

8 See WANG, C., The Total Ban on the Consumption of wildlife protects people's lives, health and safety, People's Daily, 31.19. 2020 .

128 Derecho Animal. Forum of Animal Law Studies, vol. 11/2 
civilization and environmental protection.

As for law enforcement requirements and measures, Article VI of the "Decision" stipulates that the relevant people's governments at various levels and departments shall improve the law enforcement management system, define the subject of law enforcement responsibility, implement law enforcement and management responsibilities, strengthen coordination, increase the level of oversight, inspection and accountability, and strictly investigate and punish violations of the "Decision" and the relevant regulations. Illegal business sites and illegal business operators shall also be banned or closed down in accordance with the law. This means that once a former legal breeding facility is declared illegal by the "Decision", it must be closed when it takes effect. Appropriate compensation measures should be taken for farmers for wildlife that are banned from captive breeding and eating. Some of those farmers point out that they are in a dilemma: they do not know whether to keep raising or feeding their wildlife and they are reluctant to abandon them. Since a lot of farmers borrowed a large amount of money from banks, there is a debt and financial problem that needs to be solved for those farmers. ${ }^{9}$

As for the Blacklist and Whitelist as well as the formulate and adjustments of supporting provisions, Article VII of the "Decision" stipulates that the State Council and its relevant departments as well as provinces, autonomous regions and municipalities directly under the central government shall, in accordance with the "Decision" and relevant laws, formulate and adjust the relevant catalogues and supporting provisions. The government has to compensate the farmers for making formerly legal captive breeding of some wildlife now illegal. To this end, the Article also provides that the State Council and the local people's governments shall take necessary measures to provide corresponding guarantees for the implementation of the "Decision". The relevant local people's governments shall support, guide and help the affected farmers to adjust and transform their production and operation activities, and give certain compensations according to the different situations.

Article VIII of the decision indicate the "Decision" shall take effect beginning February 24, 2020. As the COVID-19 epidemic continued at that time, the urgency of the implementation of the "Decision" was illustrated.

\section{The main highlights of the "Decision"}

The need for prohibition, restriction, punishment and standardized regulation in the "Decision" is based on a broad consensus in the whole society: it can force people to form a responsible and environmental friendly diet to the state and society, and force the wildlife breeding industry to adjust to an environmentally friendly production that is responsible to the country and civilization of society. The "Decision" is a legal document that reflects the progress of Chinese social and ecological civilization. Throughout the whole text, we can find that the "Decision" has the following highlights:

First, it reflects the legislative attitude of being practical and realistic: it not only abolished the bad habit in society, but also maintained the basic stability of the economy. The civilization of human society is advancing forward, so we have to develop a responsible diet for the country and society, but the legislation cannot go beyond and be one-size-fits-all. At present our country has reached the point where we do not need to depend on wildlife to provide protein and has also achieved an all-round well-off life. It has also come to a window period to keep a proper distance from wild animals and cultivate an ecological civilization and environmentally friendly lifestyle. It is necessary, based on the precautionary principle, to completely eliminate the phenomenon of eating wildlife mindlessly. For the use of wildlife, it is necessary to establish a scientific and accurate list of the areas where consumption and other uses are prohibited. We should not adopt a one-size-fits-all approach and cause unnecessary damage to scientific research and the traditional Chinese medicine industry. Considering the current situation of the standardized development of captive breeding industry, as well as the difficulty of completely stopping the use of wildlife for medicine and scientific research, the "Decision" opened a door, namely that captive breeding wildlife can be used for medical, scientific research, and exhibition purposes, with more rigorous and standardized management measures and more harsh examination, approval, inspection, and quarantine regulations, as well as law enforcement. As for the transformation or adjustment of the captive breeding industry, the "Decision" requires local governments to give certain compensation, which is conducive to protecting the basic interests of farmers and enterprises. As for the transformation of the traditional Chinese medicine industry using wildlife and their products as raw materials, a sound transformation plan will be made later according to the possibility of the transformation, the difficulty of the transformation, and the research and development progress of alternative technologies. The next step is for the state to give some fiscal support to the local governments, otherwise some local

\footnotetext{
9 See ZHANG, K., The Wildlife Breeding Industry is at a Loss: Where to Go for the 14 Million Workers", the First Finance and Economics 2020-03-05: https://3g.163.com/news/article/F6UAB7T50001899O.html?isFromOtherWeb=true
} 
governments in financial difficulties will not be able to fully realize the compensation for breeding farmers.

Second, the Blacklist and the Whitelist were combined to delimit the boundary between illegal and legal. There must be a range of wildlife that is not allowed to be eaten. The "decision" sets out the range and list of wildlife that are not allowed to be eaten in Articles I and II. From the provision, the "Decision" expanded the scope of the protection on wildlife species. In addition to the ban on hunting, trading, transportation, and eating of wild animals in the existing laws and regulations, it also includes a total ban on eating general terrestrial wildlife living in the wild or raised by human and animals with "three values". It also includes a total ban on hunting, trading, and transporting terrestrial wildlife naturally reproduced in the wild for the purpose of consumption. The Blacklist stipulated by the Standing Committee of the National People's Congress is a great historical progress of the civilization of the rule of law. Next, for wildlife bred in captivity, it is necessary to strictly restrict and regulate them based on the needs of civilization development. It is important to note that the purposes of artificial breeding of wild animals are diverse: some are for research purposes, some are for the purpose of restoring numbers of the species, some are for exhibition, and others are for eating, fur, and raw materials for traditional Chinese medicine. Thus, the "Decision" has taken a big step forward, expanding the scope of previous prohibitions. According to the "Decision", wildlife species that are allowed to be bred in captivity cannot be eaten but can only be used for non-edible purposes under special circumstances such as scientific research, medicine, and exhibition. Relevant conditions and procedures should be more strictly implemented when using them. This is also a major advance in the rule of law. For special cases, wildlife can be bred in captivity. The list of wildlife that can be bred in captivity along with the range of domestic animals that can be eaten constitute the Whitelist. The combination of Blacklist and White list not only reflects the positive act of legislation, but also reflects the prudence of legislation. In order to make the list more scientific, Article VII of the "Decision" requires the State Council and its relevant departments and provinces, autonomous regions and municipalities directly under the central government to formulate and adjust the relevant list and other supporting provisions in accordance with the "Decision" and relevant laws. It will be tough work. In order to make the Whitelist more scientific and clearer, Ministry of Rural Agriculture of China is soliciting the opinion of society on the revision of the Livestock and Poultry Genetic Resource Directory. In terms of the content, raising Trionyx Sinensis and Rana Catesbeiana for food are allowed, raising frogs, snakes, and wild ducks are opposed. Because the opinions of society are divided, the debate in the media is intense. At present, the revision of the Whitelist at province level has not started yet.

The third is to carry out the construction of the whole chain of legal norms for each link, to stipulate the applicable or suggested applicable legal liabilities for illegal acts, serving as the "talons" of the law that brought it into play. The "Decision" not only stipulated prohibition measures for the link of eating, but also prohibited measures for the links of hunting, trading, and transporting, which reflected the rule of law thinking of the whole-process control from the front to end. As for legal liability, if there are relevant provisions in the "Wildlife Protection Act", the punishment shall be more severe. Where there is no direct provision in the current law for specific methods of punishment, the "Decision" requires, reference to the contents of the punishment to be given in accordance with the existing law. This means that a certain amount of fines which depend on the value of wildlife and its products, in accordance with the provisions of the "Wildlife protection Act" and other provisions, as well as public security detention measures in accordance with the "Public Security Administration and Punishment Law", are likely to be applied. In order to stop the entry of captive bred wildlife into the market at the source, Article VI of the "Decision" stipulates that illegal business sites and illegal operators shall be banned or closed down according to law. These severe punishment measures can make people who wish to conduct illegal hunting, trading, purchasing, importing and exporting, carrying, delivering, transporting, and eating feel scared and ensure that they do not dare to try the law. Since the reference application cannot last for long, it is necessary to stipulate the relevant administrative, civil, and criminal liabilities in the revision of the "Wildlife Protection Act" based on the implementation of the "Decision".

\section{Acknowledgement}

- Jiezhong Chang, who is a JD student at Wake Forest University, contributed to this article.

\section{References}

- CHANG, J. (Ed.), Animal Protection Law (Higher Education Press 2011) 68, 254-256 
- CHANG, J., MICHAELS, G., Animal Protection Law and Anti-cruelty Law: Experts' Suggestions and Challenges, China Environmental Science Press (2010) 7

- CHANG, J., CHANG, J., A Legal Decision Embodies Social Civilization and Ecological Progress, China Environment News, February 27, 2020

- LU, H., YANG, B., Complete Ban of Illegal Wildlife Trade and Elimination of Eating Wildlife Mindlessly: Answers to Questions from the Press by the Head of the Legislative Affairs Commission of the Standing Committee of the National People's Congress: http://www.npc.gov.cn/npc/c30834/202002/fe45c9fbd7a647d595d23601bc75c8fb.shtml

- ZHANG, K., The Wildlife Breeding Industry is at a Loss: Where to Go for the 14 Million Workers, the First Finance and Economics 2020-03-05, https://3g.163.com/news/article/F6UAB7T50001899O.html?isFromOtherWeb=true

- ZHANG, K., An interview with Jiwen Chang: COVID-19 is an alarm, in principle we should be fasting all the wildlife", on February 8, 2020: https://baijiahao.baidu.com/s?Id = $1657940428583239647 \&$ WFR $=$ spider \& for $=$ PC

- WANG, C., The Total Ban on the Consumption of wildlife protects people's lives, health and safety, People's Daily, 31.19. 2020. 